\title{
Analysis of food availability in Medan City
}

\author{
Satia Negara Lubis ${ }^{1,}{ }^{*}$, Emalisa $^{1}$, and Asri Maulidani Siregar ${ }^{2}$ \\ ${ }^{1,2}$ Department of Agribusiness. Faculty of Agriculture, Universitas Sumatera Utara, Jl. Prof. A. \\ Sofyan No. 3, Medan , 20155, North Sumatera, Indonesia.
}

\begin{abstract}
This study aims to (1) analyze the availability of food in the city of Medan (2) the availability of nutrients (energy, protein, and fat) compared to the Nutritional Adequacy Rate (RDA) (3) the diversity of food availability in the city of Medan. The research data were obtained from primary data and secondary data. The analytical method used is descriptive method using the Food Balance Sheet (FBS). The results showed that the availability of food in Medan City in 2020 was in the available category of $1,350.25$ grams/capita/day or $489.93 \mathrm{~kg} /$ capita/year. The availability of nutrients (energy, protein, and fat) of food in Medan City has exceeded the recommended nutritional adequacy rate and is classified in the available category. The diversity of food availability in the city of Medan is quite diverse.
\end{abstract}

\section{Introduction}

Availability of food in sufficient quantity and quality is needed to achieve good food security for a region. Food availability can be obtained from self-production, outside supply (imports), food reserves, and food aid (Adriani and Wirjatmadi, 2012).

Food is a fundamental human right, and it is the government's obligation to provide it to its citizens. Food shortages may cause unrest and have a negative influence on social, security, and economic issues. One of the aims of agricultural development is to provide enough and high-quality food for the whole population (Winiarti, 2015).

Along with the increase in population growth in the city of Medan every year, the increase in the need for basic food is something that cannot be avoided. According to the Central Statistics Agency, Medan City is the biggest regency/city in Indonesia, with a population of 2.26 million people. (Medan City, BPS, 2020).

The Medan City Government must be able to supply enough food to fulfill the requirements of families. As a result, information regarding Medan's food situation is required. This may be observed in the descriptions of food production, procurement, and usage, as well as the amount of per capita availability of food. One way to get a picture of the situation of food availability can be presented in a balance or table known as the Food Balance Sheet (FBS). FBS allows for a macro-level perspective of the composition of food ingredients, as well as the amount and kind of food ingredients available for consumption, allowing for a better understanding of food supply and usage, as well as the degree of availability and use of food in a given region. The objectives of this study were: 1) To

\footnotetext{
*Corresponding author: satia_waspada@yahoo.com
} 
analyze food availability in Medan City; 2) To analyze the availability of energy, protein, and fat in food groups in Medan City; 3) To analyze the diversity of food availability in the city of Medan.

\section{Methods}

\subsection{Area Determination Method}

The method of determining the research area is purposive, in the sense that it is based on specific factors that are tailored to the research goals (Singarimbun and Effendi, 1989). The study will take place in Medan.

\subsection{Research Methods}

According to (Sugiono, 2009), a descriptive approach is one that uses data or samples gathered as-is to describe or offer an overview of the item under investigation without analyzing or drawing conclusions that are applicable to the general audience.

\subsection{Sources and Data Types}

This research uses primary data and secondary data. Interviews with respondents provided primary data. Secondary data was gathered from linked organizations.

\subsection{Method of collecting data}

The data collection method was carried out through an institutional survey to several related agencies through a structured questionnaire. Respondents filled out questionnaires in two ways, namely direct interviews and using the self-administered questionnaire method.

\subsection{Sampling Method}

The sampling method used area probability sampling technique. The methodology / method of obtaining random samples based on the partition of an area / region is known as area probability sampling.

The people in this research were all from Medan's traditional marketplaces. In Medan City, there are 53 traditional markets distributed over 21 sub-districts. One market from each sub-district was chosen from each sub-district, resulting in a total of 21 marketplaces to be utilized as samples. This study used a sample of 100 food commodity dealers from 21 marketplaces in Medan.

\subsection{Data Analysis Method}

To solve the first problem, determining food availability in the city of Medan, descriptive analysis was used to examine data on food availability in the city of Medan. The information came from the Food Security Agency of Medan City. Regional food availability for a particular commodity can be formulated as follows:

$$
\mathrm{KTSP}=\mathrm{PROD}-\mathrm{SP}+(\mathrm{IP}-\mathrm{XP})-(\mathrm{F}+\mathrm{S}+\mathrm{I}+\mathrm{W})
$$




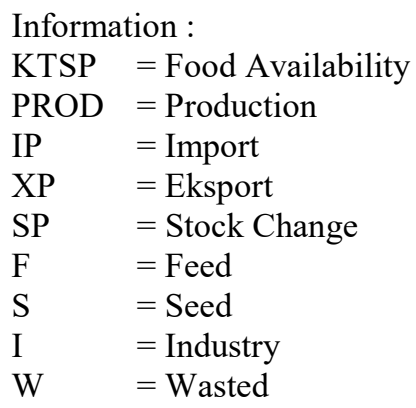

To solve the second problem, descriptive analysis was used to compare data on food availability in energy, protein, and fat in the city of Medan with energy and protein availability according to the standard Nutrition Adequacy Ratio (RDA). The protein availability is calculated by multiplying the overall availability of food for human consumption by the percentage of edible portion, then multiplying by the protein content of 100 grams of food, divided by 100 . Food availability (energy, protein, and fat) can be formulated as follows:

$$
\begin{aligned}
& \text { KSPe }=\text { KSP } \times \% \text { BDD } \times \text { Kand.e }: 100 \\
& \text { KSPp }=\text { KSP } \times \% \text { BDD } \times \text { Kand.p }: 100 \\
& \text { KSPl }=\text { KSP } \times \% \text { BDD } \times \text { Kand.l }: 100
\end{aligned}
$$

Information :

$\mathrm{KSPe}=$ Availability food energy (Kcal/cap/day)

$\mathrm{KSPp}=$ Availability food protein ( $\mathrm{gr} / \mathrm{cap} /$ day)

KSPl = Availability of dietary fat (gr/cap/day)

$\mathrm{KSP}=$ Food availability per capita (gram/day)

$\%$ BDD $=$ Edible Part

The final problem, determining the diversity of food availability in Medan City, is solved using descriptive analysis by Desirable Dietary Pattern (DDP) calculations.

\section{Result}

\subsection{Food Availability in Medan City in 2020}

Information on the availability of food in an area can be seen using the Food Balance Sheet (FBS). The availability of food in a certain region is crucial to know in order to figure out how to feed everyone in the area.

Based on the calculation of food availability through the Food Balance Sheet of Medan City in 2020, it can be seen that the availability of food for consumption by the people of Medan City within one year, in quantum form (volume), namely grams/capita/day, $\mathrm{kg} /$ capita/year and tons/year can be seen in Table 1 below: 
Table 1 Food availability in Medan City in 2020

\begin{tabular}{llccr}
\hline No & Group of & \multicolumn{3}{c}{ Food Availability } \\
\cline { 3 - 5 } & Foods & Gram/capita/day & Kg/capita/year & Ton/year \\
\hline 1 & Grains & 421,03 & 153,68 & $275.732,87$ \\
2 & Starchy Food & 28,91 & 10,55 & $15.243,03$ \\
3 & Sugar & 31,43 & 8,26 & $151.121,30$ \\
4 & Oily Fruits/Seeds & 92,07 & 33,90 & $69.374,44$ \\
5 & Fruits & 143,55 & 52,40 & $121.074,59$ \\
6 & Vegetables & 288,56 & 105,33 & $260.776,30$ \\
7 & Meat & 36,70 & 13,42 & $30.387,93$ \\
8 & Eggs & 36,61 & 13,00 & $33.520,13$ \\
9 & Milk & 18,04 & 6,58 & $16.613,99$ \\
10 & Fish & 208,41 & 76,07 & $94.321,25$ \\
11 & Oil and Fat & 45,84 & 16,73 & $319.746,55$ \\
\hline & Total & $\mathbf{1 . 3 5 0 , 2 5}$ & $\mathbf{4 8 9 , 9 3}$ & $\mathbf{1 . 3 8 7 . 9 1 2 , 5 5}$ \\
\hline
\end{tabular}

(Source: Processed Primary Data, 2020)

According to Table 1, total food availability for Medan City people in 2020 is $1,387,912.55$ tons/year, with food availability per day of $1,350.25$ grams/capita/day and $489.93 \mathrm{~kg} /$ capita/year.

\subsection{Availability of Energy, Protein and Fat}

Based on Medan City's Food Balance Sheet (FBS) figures in 2020, Medan City's food availability in terms of food quality/nutrient content (Energy, Protein, and Fat) compared to the Nutrition Adequacy Ratio (RDA) for each food group is given in Table 2:

Tabel 2 Availability of energy, protein and fat in Medan City in 2020

\begin{tabular}{llccc}
\hline No & $\begin{array}{l}\text { Group of } \\
\text { Food }\end{array}$ & $\begin{array}{c}\text { Energy } \\
\text { (Kcal/capita/day) }\end{array}$ & $\begin{array}{c}\text { Protein } \\
\text { (Gram/capita/day) }\end{array}$ & $\begin{array}{c}\text { Fat } \\
\text { (Gram/capita/day) }\end{array}$ \\
\hline 1 & Grains & $1.491,08$ & 37,34 & 5,55 \\
2 & Starchy & 35,48 & 0 & 0 \\
& Food & 115,00 & 0 & 0 \\
3 & Sugar & 201,73 & 11,49 & 11,38 \\
4 & Oily & & & \\
& Fruits/Seeds & 54,34 & 0,62 & 0 \\
5 & Fruits & 65,06 & 3,93 & 1,06 \\
6 & Vegetables & 100,77 & 6,64 & 8,05 \\
7 & Meat & 50,77 & 3,94 & 0,64 \\
8 & Eggs & 11,00 & 0,58 & 2,74 \\
9 & Milk & 128,36 & 23,21 & 46,81 \\
10 & Fish & 413,00 & 0,03 & $\mathbf{7 9 , 2 8}$ \\
11 & Oil and Fat & $\mathbf{2 . 6 6 6 , 5 9}$ & $\mathbf{8 8 , 0 6}$ & $\mathbf{7 5 , 0 0}$ \\
\hline & Total & & $\mathbf{6 3 , 0 0}$ & \\
\hline
\end{tabular}

(Source: Processed Primary Data, 2020)

According to Table 2, the availability of energy in Medan City of 2,666.59 $\mathrm{kcal} / \mathrm{capita}$ /day has met the minimum energy adequacy standard recommended by the 2018 WNPG of 2,310.00 kcal/capita/day. The availability of protein in Medan City of 88.06 
grams/capita/day has exceeded the standard protein adequacy rate by the 2018 WNPG of 63.00 grams/capita/day. The availability of fat in Medan City of 79.28 grams/capita/day has exceeded the standard fat adequacy rate by the $2018 \mathrm{WNPG}$ of 75.00 grams/capita/day.

The results of the analysis show that the availability of energy, protein and fat in the food group has exceeded the expected/recommended consumption rate in accordance with the nutritional adequacy rate standard by the 2018 National Food Service Widyakarya (WNPG) available.

\subsection{Food Diversity in Medan City in 2020}

Food availability in terms of diversity based on the Desirable Dietary Pattern (DDP). Desirable Dietary Pattern availability level is calculated based on the availability of Energy Food Balance Sheet.

The DDP method is used to assess the level of diversity of food availability at a time with a score of 100 as the ideal DDP (BKP, 2014). The overall DDP score for each food group in Medan City in 2020 is shown in Table 3 below:

Tabel 3. Food Availability DDP Calculation in 2020

\begin{tabular}{llrrrrrr}
\hline No & $\begin{array}{l}\text { Group of } \\
\text { Foods }\end{array}$ & $\begin{array}{c}\text { Energy } \\
\text { (Calories) }\end{array}$ & \%AKE & Weight & $\begin{array}{c}\text { Real } \\
\text { Score }\end{array}$ & $\begin{array}{c}\text { Max } \\
\text { Score }\end{array}$ & $\begin{array}{c}\text { DDP } \\
\text { Score }\end{array}$ \\
\hline 1 & Grains & 1491 & 69,35 & 0,5 & 34,67 & 25 & 25 \\
2 & Tubers & 37 & 1,72 & 0,5 & 0,86 & 2,5 & 0,86 \\
3 & Animal Food & 289 & 13,44 & 2,0 & 26,88 & 24 & 24 \\
4 & Oil and Fat & 412 & 19,16 & 0,5 & 9.58 & 5 & 5 \\
5 & Oily & 69 & 3,21 & 0,5 & 1,60 & 1 & 1 \\
& Fruits/Seeds & & & & & & \\
6 & Nuts & 133 & 6,19 & 2,0 & 12,37 & 10 & 10 \\
7 & Sugar & 81 & 3,77 & 0,5 & 1,88 & 2,5 & 1,88 \\
8 & Vegetable and & 119 & 5,53 & 5,0 & 27,67 & 30 & 27,67 \\
& Fruit & & & & & & - \\
9 & Etc & - & - & - & - & - & $\mathbf{9 5 , 4 1}$ \\
\hline & Total & $\mathbf{2 6 3 1}$ & $\mathbf{1 2 2 , 3 7}$ & & $\mathbf{1 1 5 , 5 3}$ & $\mathbf{1 0 0}$ & $\mathbf{9}$ \\
\hline
\end{tabular}

(Source: Processed Primary Data, 2020)

According to Table3, the Desirable Dietary Pattern (DDP) score for food availability for Medan City in 2020 is 95.41 . The DDP score is not said to be ideal because it has not reached the ideal score of 100 . When the DDP score approaches the ideal, it indicates that the condition of food availability in a certain area is highly diversified. As a result, the state of the diversity of food available in Medan may be described as extremely diversified.

\section{Conclusion}

1. Food availability in Medan City in 2020 is in the available category with a total food availability of all food groups for people of Medan City in 2020 of 1,387,912.55 tons/year or 1,350.25 grams/capita/day or $489.93 \mathrm{~kg} /$ capita/year.

2. The overall availability of calories, protein, and fat foods has fulfilled the 2018 National Food and Nutrition Widyakarya's suggested requirements for the Nutrition Adequacy Ratio (RDA)

3. According to the Desirable Dietary Pattern (DDP), the diversity of food availability in Medan is highly diversified, with a DDP score of 95.41 for food availability. 


\section{Suggestion}

1. For the governments

The goal of the activity plan in the food sector is on generating a surplus in food availability for the Medan City administration, thus the emphasis on supplying food for energy, protein, and fat has to be enhanced.

2. For the community

In order to increase food availability in Medan, the community may help by expanding local production, namely by making better use of the city's remaining land.

\section{References}

1. Adriani, M., dan Wiratmadji B. Pengantar Gizi Masyarakat. Jakarta: Kencana (2012).

2. Badan Pusat Statistik. Kota Medan dalam Angka. Medan: Badan Pusat Statistik (2020).

3. Badan Ketahanan Pangan, Kementerian Pertanian dan World Food Programme. Peta Ketahanan dan Kerentanan Pangan Indonesia 2015. Jakarta (2015).

4. Singarimbun, Masri, dan Effendi, Sofian. Metode Penelitian Survey. Jakarta: LP3ES (1989).

5. Sugiyono. Metode Penelitian Kuantitatif, Kualitatif dan $R \& D$. Bandung: Alfabeta (2009).

6. Winiarti, Diah. Analisis Rasio Ketersediaan dan Konsumsi Pangan Strategis di Kota Medan. Jurnal Penelitian UMSU, 2-3 (2015). 